\title{
INFLUENCE OF HEAT TREATMENT ON FORMATION OF HYDROXYMETHYLFURFURAL AND HYDROGEN PEROXIDE AS HEATING INDICATORS OF HONEY
}

\author{
Awad A. Mahmoud ${ }^{1}$ and Ayman A. Owayss ${ }^{2 *}$ \\ ${ }^{1}$ Food Science and Technology Dept., ${ }^{2} *$ Plant Protection Dept., \\ Fac. Agric., Fayoum Univ., Egypt. \\ *E-mail: aao01@fayoum.edu.eg
}

\begin{abstract}
The physico-chemical characteristics of fresh cotton (Gossypium vitifolium) honey were determined. The indices obtained were within their standard ranges of Egyptian, European and Codex Alimentarius honey Standards. Influences of heating at different temperatures: $60^{\circ} \mathrm{C}$, $70^{\circ} \mathrm{C}, 80^{\circ} \mathrm{C}$ and $90^{\circ} \mathrm{C}$ for $1,3 \& 5 \mathrm{~min}$. on development of hydroxymethylfurfural (HMF) and formation of hydrogen peroxide $\left(\mathrm{H}_{2} \mathrm{O}_{2}\right)$, as indicator for glucose oxidase activity were measured. The HMF content increased significantly with the prolonged of heating and time especially when honey exposed to temperatures above $70^{\circ} \mathrm{C}$. HMF values for heated samples were lower than the limits allowed by Egyptian, European and Codex Standards suggesting that HMF alone may be insufficient indicator for heating honey as a case in the system of high-temperature short-time. Heat treatments caused a gradual reduction in $\mathrm{H}_{2} \mathrm{O}_{2}$ formation which was completely inhibited by heating honey above $70^{\circ} \mathrm{C}$ for $1 \mathrm{~min}$. According to these results, it is suggested that formation of $\mathrm{H}_{2} \mathrm{O}_{2}$ could be used simultaneously with $\mathrm{HMF}$ as criteria for freshness and/or heating of honey, since glucose oxidase, which produces $\mathrm{H}_{2} \mathrm{O}_{2}$ in honey is heat sensitive enzyme. No obvious changes in organoleptic characteristics occurred due to such heat treatments of honey.
\end{abstract}

Key words: Bee honey, $\mathrm{HMF}, \mathrm{H}_{2} \mathrm{O}_{2}$ and heating.

\section{INTRODUCTION}

Distinctive characteristics of bee honey are not, primarily, due to its major components which can be found in many sweet products, but to its multitude of minor components originated from the nectar and bees themselves. Many of these substances, which give its specific aroma, flavor and some of its biological activity, are unstable over time and thermolabile. Heating has a negative effect on honey due to the loss of those substances. Some honeys tend to crystallize especially when temperature is decreased. Crystallized honey has an opaque, waxy appearance and less visual impact than liquid honey. These features are not accepted for many consumers who prefer liquid honey. In commercial processing plants, honey is usually heated to $60^{\circ} \mathrm{C}$ or above for inhibiting microorganisms, facilitating packing and delaying crystallization (Tosi, et al. 2004). Official honey standards approve major nine parameters have to be determined including reducing sugars, sucrose, fructose / glucose ratio, moisture, ash, water insoluble solids, acidity, diastase activity and HMF. These tests are laborious and time consuming. HMF or 5hydroxymethyl-2-furaldehyde, is a cyclic aldehyde formed from fructose and glucose during dehydration. High HMF content indicates deterioration of honey which mainly due unsuitable conditions during storage and / or heating of honey (Feather, et al., 1982 and Hoseney, 1984). Minor components of

Fayoum J. Agric. Res. \& Dev., Vol.22, No.2, July, 2008 
honey i.e. enzymes make it different from other sweeteners, but some treatments $e . g$. processing and prolonged storage usually reduce its enzymatic activity (Huidobro, et al. 1995). On the other hand, honey enzymes, which participate in its ripening and biological value, serve as sensitive indicators of honey treatment. These enzymes which include amylase, invertase and glucose oxidase are, ascending, heat-sensitive (Crane, 1990). The most parameters used as indicators of freshness and overheating of honey are HMF, diastase and invertase. HMF and diastase are included as international quality standards for honey but invertase is considered better than diastase as a freshness index because it is more sensitive to heating (White, et al. 1964; Gonnet, 1965; Dustmann, 1985 and Sancho, et al. 1992). Besides, some questions in the literatures need answers about the effect of high temperature-short time treatment on honey (Tosi et al, 2004).

The main of this piece of work is to study the formation of HMF and estimation of glucose oxidase activity (responsible for $\mathrm{H}_{2} \mathrm{O}_{2}$ production) during heat treatments of honey. Besides, suggesting a simple, rapid and cheap test which can enable consumers to distinguish between natural and adulterated honeys and to find out if honey was exposed to heating or not.

\section{MATERIALS AND METHODS}

This work is a completion of a previous one concerned glucose oxidase activity as a quality criterion of freshness or storage of honey (Mahmoud and Owayss, 2006).

The sampling and procedures in the present work were carried out as the following:

Sampling:

A pure cotton (Gossypium vitifolium L.) honey was harvested, by ordinarily beekeeping practices, in Aug, 2006 from the apiary of the Faculty of Agriculture, Fayoum University at Fayoum governorate, Egypt. Honeybee colonies were situated in wooden Langstroth's standard hives and headed with local $1^{\text {st }}$ hybrid Carniolan, Apis mellifera carnica, queen bees. No supplementary feeding or chemical treatments were applied to these colonies during cotton flow season.

For analysis, $5 \mathrm{~kg}$ fresh honey sample were randomly taken and transferred to the laboratory in PVC jars and the analysis samples were prepared for subsequent determinations.

\section{Physico-chemical analyses:}

Moisture content, total soluble solids were estimated by measuring refractive index (RI) using Abbe's refractometer, ash was determined by ashing at $550^{\circ} \mathrm{C}$. For acidity (as formic acid), $10 \mathrm{~g}$ honey was dissolved in $75 \mathrm{ml}$ distilled water and titrated with $0.1 \mathrm{~N} \mathrm{NaOH}, \mathrm{pH}$ values were measured and reducing and non-reducing sugars (as sucrose) were determined according to official methods of analysis reported in AOAC (1990) and Bogadanov, et al.(1997). The HMF content was determined by the UV spectrophotometric method given by White (1979). Absorbance of honey diluted with distilled water $(1: 1 \mathrm{w} / \mathrm{v})$ was measured at $420 \mathrm{~nm}$ as indication of honey color.

\section{Heat treatments:}

1- To determine HMF progress during heat treatment, honey samples ( $25 \mathrm{~g}$ each) were placed in screw test tubes, then subjected to heating in a thermostatic-shaking water bath at $60^{\circ} \mathrm{C}, 70^{\circ} \mathrm{C}, 80^{\circ} \mathrm{C}$, and $90^{\circ} \mathrm{C}$ for 1,3

Fayoum J. Agric. Res. \& Dev., Vol.22, No.2, July, 2008 
and $5 \mathrm{~min}$. for each degree. Time was calculated when temperature reached the required degree, then tubes were cooled rapidly to room temperature $\left(25 \pm 2^{\circ} \mathrm{C}\right)$ using current tap water.

2-Another honey samples (25g each) were subjected to the same treatments and thereafter, $\mathrm{H}_{2} \mathrm{O}_{2}$ concentration $(\mathrm{ppm})$ was determined every $5 \mathrm{~min}$. from 0 min. till $190 \mathrm{~min} . \mathrm{H}_{2} \mathrm{O}_{2}$, as an indicator of glucose oxidase activity was measured according to the method reported by Lerke $\boldsymbol{e t} \boldsymbol{a l}$, (1983) and modified by López-Sabater et al, (1993). Unheated samples were compared as control.

\section{Sensory evaluation:}

Sensory evaluation of heated and unheated honey was carried out using the method described by Sudha et al. (2007). The panelists were asked to evaluate the honey for color, odor and taste.

\section{Application test:}

For consumer, the following test is proposed to detect if the honey was heated or not: $10 \mathrm{~g}$ honey should be diluted with $10 \mathrm{ml}$ distilled water $(1: 1 \mathrm{w} / \mathrm{v})$ and left at room temperature $\left(25^{\circ} \mathrm{C}\right)$ for $10 \mathrm{~min}$. A crushed piece of fresh vegetables (source of catalase and peroxidase) such as peas, potatoes...etc should be added to diluted honey. In case of natural or unheated honey, air bubbles will appear and vice versa in case of adulterated or heated honey. This method could be explained according to the following equations:

1) $\mathrm{C}_{6} \mathrm{H}_{12} \mathrm{O}_{6}+\mathrm{H}_{2} \mathrm{O}+$ Glucose oxidase (in natural and unheated honey) $\rightarrow$ $\mathrm{C}_{5} \mathrm{H}_{11} \mathrm{COOH}+\mathrm{H}_{2} \mathrm{O}_{2}$

2) $2 \mathrm{H}_{2} \mathrm{O}_{2}+$ Catalase or peroxidase (in fresh vegetables) $\rightarrow 2 \mathrm{H}_{2} \mathrm{O}+\mathrm{O}_{2} \uparrow$ (bubbles in diluted honey).

\section{Statistical analysis:}

Statistical analysis was performed using the Statistical Package for Social Sciences (SPSS 14.0 for Windows ${ }^{\circledR}$, ver. 2, SPSS Inc. Chicago, IL, USA). Significance of differences was defined at $\mathrm{p}<0.05$ following Snedecor and Cochran (1967).

\section{RESULTS AND DISCUSSION}

Physico-chemical characteristics:

Results in Table 1 summarizes the physico-chemical characteristics of the freshly tested cotton honey compared to those reported in Egyptian Organization Standards (EOS) (1990), European Union Commission (EUC) (1996) and Codex Alimentarius Commission (CAC) (1998). The tested honey samples have: moisture content (15.20\%); total soluble solids $(82.0 \%)$; reducing sugars $(74.83 \%)$; sucrose $(4.58 \%)$; total acidity (37.71 $\mathrm{meq} / \mathrm{kg}$ ); HMF (6.10 ppm); ash (0.43\%) and $\mathrm{pH}(4.66)$. Absorbance of diluted honey filtrate at $420 \mathrm{~nm}$ was 0.418 . These results are near from those reported by Sahinler and Gul (2004). Tosi, et al. (2004). 
Table (1). Physico-chemical parameters of freshly cotton honey.

\begin{tabular}{|l|c|c|c|c|}
\hline Parameter & Tested Honey & CAC & EUC & EOS \\
\hline Refractive index $\left(\right.$ at $\left.25^{\circ} \mathrm{C}\right)$ & 1.4989 & -- & -- & -- \\
\hline Moisture (\%) & 15.20 & $\leq 21$ & $\leq 21$ & $\leq 20$ \\
\hline Total soluble solids (\%) & 82.00 & -- & -- & -- \\
\hline Reducing sugars (\%) & 74.83 & $\geq 65$ & $\geq 65$ & $\geq 70$ \\
\hline Sucrose (\%) & 4.58 & $\leq 5$ & $\leq 5$ & $\leq 5$ \\
\hline Total acidity (meq. formic acid / kg) & 37.71 & $\leq 50$ & $\leq 40$ & $\leq 50$ \\
\hline Ash (\%) & 0.43 & $\leq 0.6$ & $\leq 0.6$ & $\leq 0.4$ \\
\hline HMF (ppm) & 6.10 & $\leq 60$ & $\leq 40$ & $\leq 40$ \\
\hline pH & 4.66 & -- & -- & -- \\
\hline Absorbance (at 420 nm) & 0.418 & -- & -- & -- \\
\hline
\end{tabular}

$\mathrm{CAC}=$ Codex Alimentarius Commission $\quad$ EUC $=$ European Union Commission

EOS = Egyptian Organization Standards

Influence of heat treatments on HMF development:

Data in Table 2 and Figure 1 summarize the influence of heat treatments on the HMF of tested cotton honey. The HMF content increased obviously from $6.10 \mathrm{ppm}$ for unheated sample to $6.22,6.88,9.70$, and $16.90 \mathrm{ppm}$ by heating for 5 min. at $60^{\circ} \mathrm{C}, 70{ }^{\circ} \mathrm{C}, 80^{\circ} \mathrm{C}$, and $90^{\circ} \mathrm{C}$, respectively. It was noticed that $\mathrm{HMF}$ increased slowly until $70^{\circ} \mathrm{C}$, then a sharp increase was observed at higher temperatures.

Heating at these temperatures for $1,3 \& 5$ min. exhibited that rate of HMF formation was affected by heating time, since this rate was higher in the $1^{\text {st }}$ stage of heating than in the $2^{\text {nd }}$ stage especially at $90^{\circ} \mathrm{C}$, then at $80^{\circ} \mathrm{C}$. These observations agree with those given by Tosi $\boldsymbol{e t}$ al, (2001) who recorded that $\mathrm{HMF}$ increased from $10.1 \mathrm{ppm}$ to $32.8 \mathrm{ppm}$ by heating of honey for $1 \mathrm{~min}$. at $100^{\circ} \mathrm{C} \& 140^{\circ} \mathrm{C}$, respectively. Also, Karabournioti and Zervalaki (2001) found that heating cotton honey for $24 \mathrm{~h}$ at $35^{\circ} \mathrm{C}, 45^{\circ} \mathrm{C}, 55^{\circ} \mathrm{C}, 65^{\circ} \mathrm{C} \& 75^{\circ} \mathrm{C}$ increased HMF from $9.7 \mathrm{ppm}$ (unheated) to $9.9,11.40,16.50,52.70 \& 173.40$ ppm, respectively.

Table (2). Effect of heat treatment on HMF formation in cotton honey.

\begin{tabular}{|c|c|c|c|c|}
\hline $\begin{array}{c}\text { Heating } \\
\text { Temperature }\left({ }^{\mathbf{o}} \mathbf{C}\right)\end{array}$ & $\begin{array}{c}\text { Time of } \\
\text { heating } \\
(\mathbf{m i n} .)\end{array}$ & $\begin{array}{c}\text { HMF } \\
\text { formed } \\
(\mathbf{p p m})\end{array}$ & $\begin{array}{c}\text { Rate of } \\
\text { Increase in } \\
\text { HMF (\%) }\end{array}$ & $\begin{array}{c}\text { Mean } \\
\mathbf{\mathbf { S d }}\end{array}$ \\
\hline Control & $\mathbf{0}$ & 6.10 & 0.00 & $6.00 \pm 0.01$ \\
\hline \multirow{3}{*}{$\mathbf{6 0}$} & $\mathbf{1}$ & 6.12 & 0.33 & $6.12 \pm 0.01$ \\
\cline { 2 - 5 } & $\mathbf{3}$ & 6.16 & 0.98 & $6.16 \pm 0.01$ \\
\cline { 2 - 5 } & $\mathbf{5}$ & 6.22 & 1.97 & $6.22 \pm 0.01$ \\
\hline \multirow{3}{*}{$\mathbf{7 0}$} & $\mathbf{1}$ & 6.64 & 8.85 & $6.64 \pm 0.00$ \\
\cline { 2 - 5 } & $\mathbf{3}$ & 6.75 & 10.65 & $6.75 \pm 0.02$ \\
\cline { 2 - 5 } & $\mathbf{5}$ & 6.88 & 12.79 & $6.88 \pm 0.03$ \\
\hline \multirow{3}{*}{$\mathbf{8 0}$} & $\mathbf{1}$ & 8.65 & 41.80 & $8.65 \pm 0.01$ \\
\hline \multirow{3}{*}{$\mathbf{9 0}$} & $\mathbf{3}$ & 9.12 & 49.51 & $9.12 \pm 0.02$ \\
\cline { 2 - 5 } & $\mathbf{5}$ & 9.70 & 59.02 & $9.70 \pm 0.02$ \\
\hline & $\mathbf{1}$ & 14.28 & 134.10 & $14.28 \pm 0.01$ \\
\cline { 2 - 5 } & $\mathbf{3}$ & 15.67 & 156.88 & $15.67 \pm 0.01$ \\
\hline \multirow{3}{*}{} & $\mathbf{5}$ & 16.90 & 177.05 & $16.90 \pm 0.01$ \\
\hline
\end{tabular}

Fayoum J. Agric. Res. \& Dev., Vol.22, No.2, July, 2008 


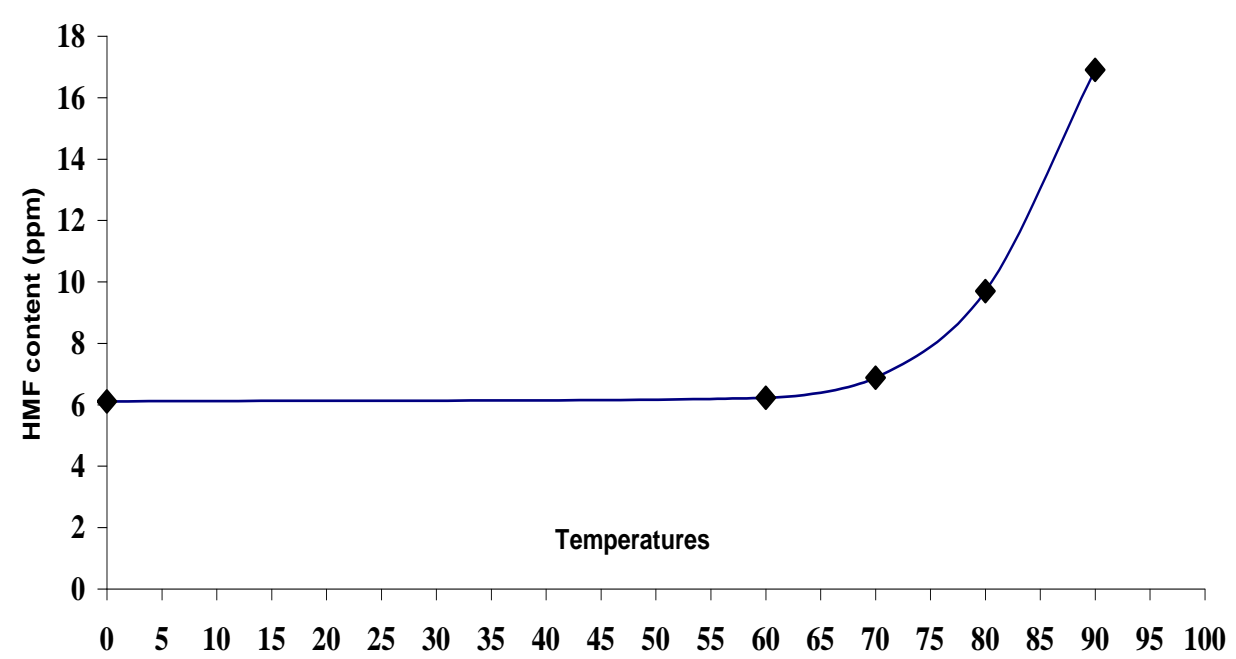

Fig. (1). Effect of heating temperatures for 5 min on HMF formation in cotton honey

\section{Influence of heat treatments on $\mathrm{H}_{2} \mathrm{O}_{2}$ formation:}

Data in Table 3 and Figures $2 \& 3$ showed that $\mathrm{H}_{2} \mathrm{O}_{2}$ was affected by heat treatments which caused a gradual decline in its formation which was completely inhibited by heating of honey above $70^{\circ} \mathrm{C}$.

Also, formation of $\mathrm{H}_{2} \mathrm{O}_{2}$ was affected by both temperature and heating time. However, heating of honey at $60^{\circ} \mathrm{C}$ caused an increase of induction period (the period required to begin $\mathrm{H}_{2} \mathrm{O}_{2}$ formation) which increased from 5 min. for control to $15,20 \& 20 \mathrm{~min}$. by heating for $1,3 \& 5 \mathrm{~min}$., respectively. But, heating of honey at $70^{\circ} \mathrm{C}$ extended the induction period from $5 \mathrm{~min}$. for control to $105,115 \& 115 \mathrm{~min}$. by heating for 1,3 and $5 \mathrm{~min}$., respectively. Besides, $\mathrm{H}_{2} \mathrm{O}_{2}$ content was very low compared to control or even honey samples heated at $60^{\circ} \mathrm{C}$.

Meanwhile, by heating of honey at $80^{\circ} \mathrm{C}$ for 1,3 and 5 min., glucose oxidase activity was completely inhibited. Also, it was noticed that the fluctuating rate of $\mathrm{H}_{2} \mathrm{O}_{2}$ formation was affected by both of temperature and time. Some other reasons reported by Postmes (1995) and Kerkivliet (1996) who explained that decline in $\mathrm{H}_{2} \mathrm{O}_{2}$ may be attributed to the presence of certain reducing components in honey. 
Awad A. Mahmoud \& Ayman A. Owayss

Table (3). Effect of heat treatment on hydrogen peroxide formation (ppm) in cotton honey.

\begin{tabular}{|c|c|c|c|c|c|c|c|c|c|c|}
\hline \multirow{2}{*}{$\begin{array}{l}\text { Time } \\
\text { (min) }\end{array}$} & \multirow{2}{*}{ Control } & \multicolumn{3}{|c|}{ Heating for $1 \mathrm{~min}$} & \multicolumn{3}{|c|}{ Heating for $3 \mathrm{~min}$} & \multicolumn{3}{|c|}{ Heating for $5 \mathrm{~min}$} \\
\hline & & $60^{\circ} \mathrm{C}$ & $7^{\circ} \mathrm{C}$ & $80^{\circ} \mathrm{C}$ & $60^{\circ} \mathrm{C}$ & $7^{\circ} \mathrm{C}$ & $80^{\circ} \mathrm{C}$ & $60^{\circ} \mathrm{C}$ & $7^{\circ} \mathrm{C}$ & $80^{\circ} \mathrm{C}$ \\
\hline 0 & 0.00 & 0.00 & 0.00 & 0.00 & 0.00 & 0.00 & 0.00 & 0.00 & 0.00 & 0.00 \\
\hline 5 & 0.11 & 0.00 & 0.00 & 0.00 & 0.00 & 0.00 & 0.00 & 0.00 & 0.00 & 0.00 \\
\hline 10 & 0.81 & 0.00 & 0.00 & 0.00 & 0.00 & 0.00 & 0.00 & 0.00 & 0.00 & 0.00 \\
\hline 15 & 1.15 & 0.06 & 0.00 & 0.00 & 0.00 & 0.00 & 0.00 & 0.00 & 0.00 & 0.00 \\
\hline 20 & 1.14 & 0.19 & 0.00 & 0.00 & 0.08 & 0.00 & 0.00 & 0.03 & 0.00 & 0.00 \\
\hline 25 & 1.12 & 0.49 & 0.00 & 0.00 & 0.21 & 0.00 & 0.00 & 0.13 & 0.00 & 0.00 \\
\hline 30 & 1.09 & 0.85 & 0.00 & 0.00 & 0.42 & 0.00 & 0.00 & 0.27 & 0.00 & 0.00 \\
\hline 35 & 1.08 & 1.13 & 0.00 & 0.00 & 0.65 & 0.00 & 0.00 & 0.45 & 0.00 & 0.00 \\
\hline 40 & 1.06 & 1.33 & 0.00 & 0.00 & 0.87 & 0.00 & 0.00 & 0.65 & 0.00 & 0.00 \\
\hline 45 & 1.05 & 1.46 & 0.00 & 0.00 & 1.03 & 0.00 & 0.00 & 0.82 & 0.00 & 0.00 \\
\hline 50 & 1.02 & 1.52 & 0.00 & 0.00 & 1.15 & 0.00 & 0.00 & 0.96 & 0.00 & 0.00 \\
\hline 55 & 0.99 & 1.53 & 0.00 & 0.00 & 1.22 & 0.00 & 0.00 & 1.06 & 0.00 & 0.00 \\
\hline 60 & 0.96 & 1.52 & 0.00 & 0.00 & 1.25 & 0.00 & 0.00 & 1.14 & 0.00 & 0.00 \\
\hline 65 & 0.94 & 1.50 & 0.00 & 0.00 & 1.28 & 0.00 & 0.00 & 1.19 & 0.00 & 0.00 \\
\hline 70 & 0.91 & 1.48 & 0.00 & 0.00 & 1.28 & 0.00 & 0.00 & 1.22 & 0.00 & 0.00 \\
\hline 75 & 0.88 & 1.44 & 0.00 & 0.00 & 1.26 & 0.00 & 0.00 & 1.23 & 0.00 & 0.00 \\
\hline 80 & 0.84 & 1.40 & 0.00 & 0.00 & 1.25 & 0.00 & 0.00 & 1.24 & 0.00 & 0.00 \\
\hline 85 & 0.81 & 1.36 & 0.00 & 0.00 & 1.23 & 0.00 & 0.00 & 1.24 & 0.00 & 0.00 \\
\hline 90 & 0.78 & 1.31 & 0.00 & 0.00 & 1.23 & 0.00 & 0.00 & 1.24 & 0.00 & 0.00 \\
\hline 95 & 0.71 & 1.26 & 0.00 & 0.00 & 1.20 & 0.00 & 0.00 & 1.23 & 0.00 & 0.00 \\
\hline 100 & 0.67 & 1.21 & 0.00 & 0.00 & 1.17 & 0.00 & 0.00 & 1.23 & 0.00 & 0.00 \\
\hline 105 & 0.65 & 1.17 & 0.01 & 0.00 & 1.15 & 0.00 & 0.00 & 1.21 & 0.00 & 0.00 \\
\hline 110 & 0.61 & 1.12 & 0.03 & 0.00 & 1.12 & 0.00 & 0.00 & 1.20 & 0.00 & 0.00 \\
\hline 115 & 0.57 & 1.06 & 0.05 & 0.00 & 1.09 & 0.01 & 0.00 & 1.19 & 0.01 & 0.00 \\
\hline 120 & 0.55 & 1.01 & 0.08 & 0.00 & 1.07 & 0.01 & 0.00 & 1.18 & 0.02 & 0.00 \\
\hline 125 & 0.51 & 0.96 & 0.10 & 0.00 & 1.04 & 0.02 & 0.00 & 1.17 & 0.03 & 0.00 \\
\hline 130 & 0.48 & 0.91 & 0.13 & 0.00 & 1.01 & 0.03 & 0.00 & 1.15 & 0.04 & 0.00 \\
\hline 135 & 0.45 & 0.86 & 0.14 & 0.00 & 0.98 & 0.03 & 0.00 & 1.14 & 0.05 & 0.00 \\
\hline 140 & 0.45 & 0.82 & 0.16 & 0.00 & 0.95 & 0.05 & 0.00 & 1.13 & 0.05 & 0.00 \\
\hline 145 & 0.43 & 0.78 & 0.18 & 0.00 & 0.92 & 0.05 & 0.00 & 1.11 & 0.07 & 0.00 \\
\hline 150 & 0.42 & 0.74 & 0.20 & 0.00 & 0.91 & 0.06 & 0.00 & 1.10 & 0.08 & 0.00 \\
\hline 155 & 0.42 & 0.70 & 0.22 & 0.00 & 0.87 & 0.06 & 0.00 & 1.09 & 0.09 & 0.00 \\
\hline 160 & 0.42 & 0.67 & 0.24 & 0.00 & 0.83 & 0.08 & 0.00 & 1.07 & 0.11 & 0.00 \\
\hline 165 & 0.42 & 0.64 & 0.26 & 0.00 & 0.81 & 0.08 & 0.00 & 1.06 & 0.13 & 0.00 \\
\hline 170 & 0.42 & 0.61 & 0.29 & 0.00 & 0.78 & 0.10 & 0.00 & 1.05 & 0.15 & 0.00 \\
\hline 175 & 0.42 & 0.58 & 0.32 & 0.00 & 0.76 & 0.10 & 0.00 & 1.04 & 0.17 & 0.00 \\
\hline 180 & 0.42 & 0.57 & 0.34 & 0.00 & 0.74 & 0.12 & 0.00 & 1.03 & 0.19 & 0.00 \\
\hline 185 & 0.42 & 0.54 & 0.36 & 0.00 & 0.73 & 0.13 & 0.00 & 1.02 & 0.20 & 0.00 \\
\hline 190 & 0.42 & 0.53 & 0.36 & 0.00 & 0.73 & 0.13 & 0.00 & 1.02 & 0.20 & 0.00 \\
\hline
\end{tabular}

Sensory evaluation:

Sensory evaluation of heated honey at $60^{\circ} \mathrm{C}, 70^{\circ} \mathrm{C}, 80^{\circ} \mathrm{C}$ and $90^{\circ} \mathrm{C}$ for 5 min. compared to unheated honey (control) was evaluated and the results are

Fayoum J. Agric. Res. \& Dev., Vol.22, No.2, July, 2008 
summarized in Table 4. Data shown in this table revealed no obvious differences in color, odor and taste of honey samples as a result of heat treatments.

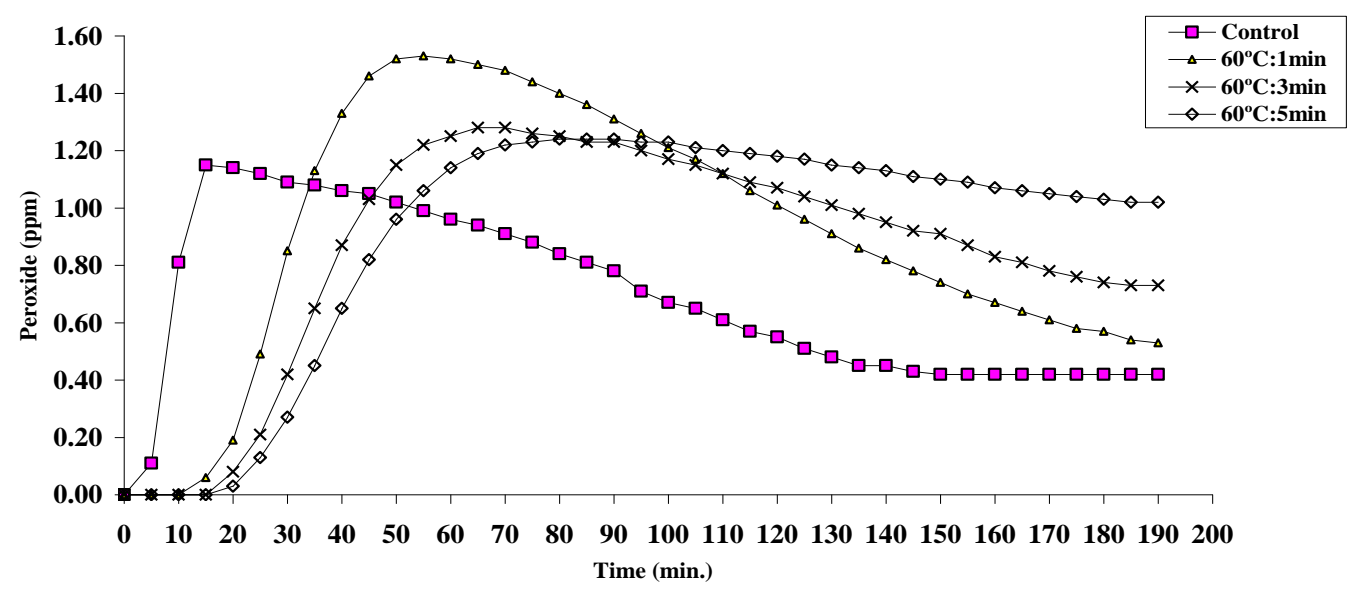

Fig. (2). Effect of heating time at $60^{\circ} \mathrm{C}$ on peroxide formation

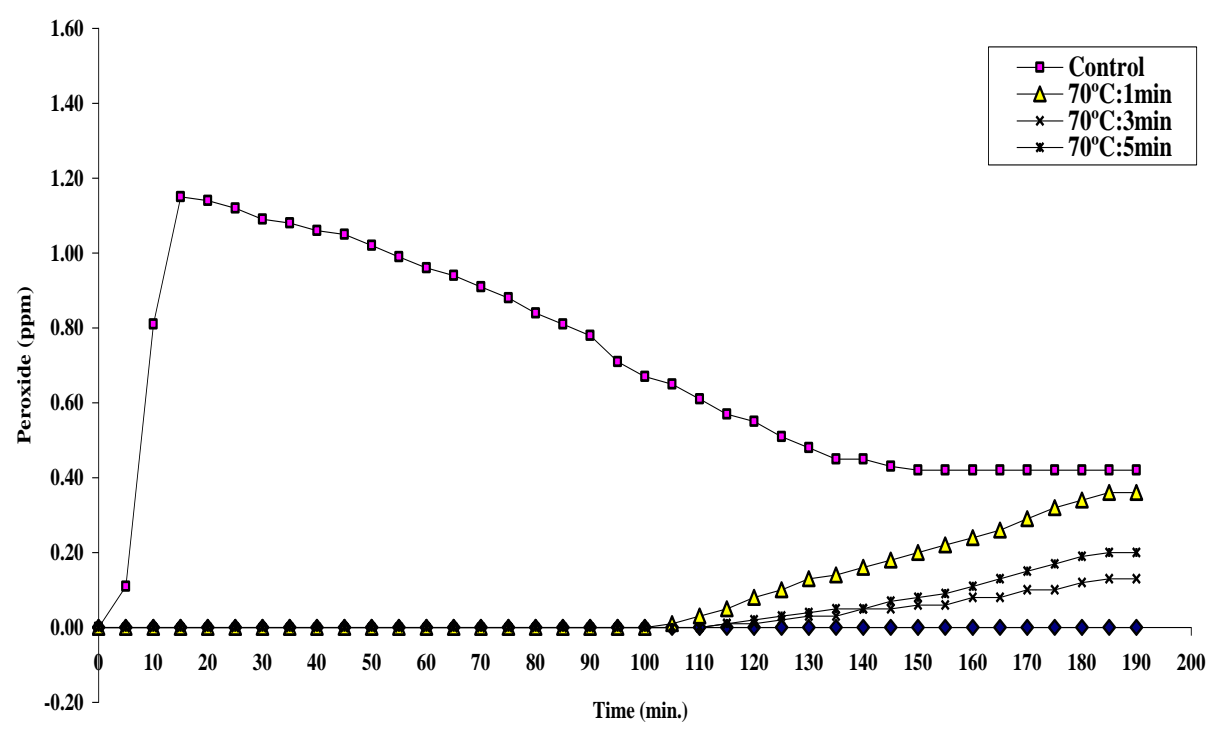

Fig. (3). Effect of heating time at $70^{\circ} \mathrm{C}$ on peroxide formation

Table (4). Sensory evaluation of heated honey samples at different temperatures for 5 min compared to non heated (control).

\begin{tabular}{|c|c|c|c|c|c|}
\hline \multirow{2}{*}{ Parameter } & $\begin{array}{c}\text { Control } \\
\text { honey }\end{array}$ & $\mathbf{6 0}^{\circ} \mathbf{C}$ & $\mathbf{7 0}^{\circ} \mathbf{C}$ & $\mathbf{8 0}^{\circ} \mathbf{C}$ & $\mathbf{9 0}^{\circ} \mathbf{C}$ \\
\hline Color (20) & $18.00 \pm 0.20$ & $17.97 \pm 0.25$ & $18.10 \pm 0.30$ & $18.17 \pm 0.06$ & $18.50 \pm 0.60$ \\
\hline Odor (40) & $37.97 \pm 0.06$ & $37.50 \pm 0.17$ & $38.53 \pm 0.21$ & $38.70 \pm 0.10$ & $39.00 \pm 0.17$ \\
\hline Taste (40) & $37.03 \pm 0.06$ & $36.80 \pm 0.10$ & $37.53 \pm 0.06$ & $37.63 \pm 0.15$ & $38.03 \pm 0.15$ \\
\hline
\end{tabular}

Fayoum J. Agric. Res. \& Dev., Vol.22, No.2, July, 2008 
Application test:

The results of that test revealed that heating at $80^{\circ} \mathrm{C}$ and more for $1 \mathrm{~min}$. inhibited the glucose oxidase activity.

\section{CONCLUSION}

According to the present findings, it could be concluded that HMF determination is not sufficient for the detection of short time-heating of honey. Exposing honey in a thermal treatment till $90^{\circ} \mathrm{C}$ for 5 min. caused a significant increase in HMF content. But, this increase was accepted by Egyptian, European and Codex Standards. Meanwhile, utilization of $\mathrm{H}_{2} \mathrm{O}_{2}$, as indicator for glucose oxidase activity, may be useful as an index of heating. Also, it could be suggested that, utilization of this procedure in the standard methods can help detection of the genuineness of honey and /or heating.

\section{Acknowledgement:}

The authors are indebted to Prof. Dr. M .A. Sarhan, Prof. of Food Science and Technology, for his continuous interest and encouragement.

\section{REFERENCES}

AOAC (1990). Official methods of analysis of the Association of Official Analytical Chemists. $15^{\text {th }}$ ed. Arligton, Virginia, USA.

Bogdanov, S.; Martin, P., and Lüllmann, C. (1997). Harmonised methods of the European Honey Commission. Apidologie Extra issue, 53-55. Ger.

Codex Alimentarious Commission, CAC (1998). Codex Alimentarious Draft revised for honey CAD CX P 5/102, CI, 1998/12-S 1998, FAO: Rome, Italy.

Crane, E. (1990). Bees and Beekeeping. Scientific, Practice and World Resources. $1^{\text {st }}$ ed., Heinemann Newnes, Halley Court, Jordan Hill, Oxford OX2 8EJ, London, UK.

Dustmann, J. H; Praagh, J. P. and Bote, K. (1985). Zur bestimmung von diastase, invertase und HMF in honig. Apidologie 16 (1): 19-30.

Egyptian Organizition Standards (1990). Egyptian Honey Standards: Inspecting and Testing. EOS Part I: Bee Honey. EOS No 355 P1. Cairo, Egypt.

European Union Commission, EUC (1996). Proposal for a directive of the European council relating to honey. EUD Document 96/0114: Bruxelles, Belgium.

Feather, M.S; Harris D.W. and Nichols S.B. (1982). Routes of conversion of d-xilose, hexouronics acids and 1-ascorbic acid to 2-furaldehyde, Journal of Organic Chemistry 37, pp. 1600-1606.

Gonnet, M. (1965). Les modifications de la composition chimique des miels au cours de la conservation. Ann Abeille 8 (2), 129-146.

Hoseney, R.C. (1984). Chemical changes in carbohydrates produced by thermal processing. Journal of Chemical Education 61, pp. 308-312.

Huidobro, J. F., Santana, F. J., Sanchez, M. P.; Sancho, S. M. and SimalLozano, J. (1995). Diastase, invertase and $B$-glucosidase activities in fresh honey from north-west Spain. J. Apic. Res., 34 (1): 39-44.

Fayoum J. Agric. Res. \& Dev., Vol.22, No.2, July, 2008 
Karabournioti, S. and Zervalaki, P. (2001). The effect of heating on honey HMF and invertase, Apiacta 36 (4), pp. 177-181.

Kerkivliet, J. D. (1996). Screening method for the determination of peroxide accumulation in honey and relation with HMF content. J. Apic. Res. 35 (3/4): 110-117.

Lerke, P. A.; Porcuna, M. H. and Chen, H. B. (1983). Screening test for histamine in fish. J. Food Sci. 48 (1): 155-157.

López-Sabater, E.I.; Rodriguez-Jerez, J.J; Roig-Sagues, A.X; MoraVentura, M.T. (1993) Determination of histamine in fish using an enzymic method. Food Additives and Contamination 10 (5): 593-602.

Mahmoud, A. A. and Owayss, A. A. (2006). A modified method to determine hydrogen peroxide activity as a quality criterion of bee honey. Annals of Agric Sci., Moshtohor 44, No. 4: 1629 - 1639 pp.

Postmes, T. (1995). Honey dressings for burns, a two-way approach. Report of the department of internal medicine. Academic Hospital; Maastricht, the Netherlands $\left(2^{\text {nd }}\right.$ ed. $)$.

Sahinler, N. and Gul, A. (2004). Biochemical composition of honeys produced in Turkey. J. Apic. Res. 43 (2) 53-56.

Sancho, M.T.; Muniategai, S.; Huidobro, J.F. and Simal, J. (1992). Aging of honey. J. Agric. Food Chem. 40, 134-138.

Snedecor, G.W. and Cochran, W.G. (1967). Statistical methods. The Iowa State Univ. Press. Ames, Iowa, USA. $6^{\text {th }}$ ed.

Sudha, M.L; Vetrimani, R. and Leelavathi, K. (2007). Influence of fiber from different cereals on the rheological characteristics of wheat flour dough and on biscuit quality. Food Chem., 100: 1365-1370.

Tosi, E. A.; Ciappini, M.C.; Ré, E. and Lucero, H. (2001). Honey thermal treatment effects on hydroxymethylfurfural content. Food Chemistry 77 pp. 71-74.

Tosi, E. A; Ré, E.; Lucero, H. and Bulacio, L. (2004). Effect of honey high temperature short time heating on parameters related to quality, crystallization phenomena and fungal inhibition. Food Chemistry 37(6) 669-678.

White, J.W. (1979). Spectrophotometric method for determination of hydroxymethylfurfural in honey. J. Assoc. of Anal. Chem. 62 (3): 509511.

White, J.W.; Kushnir, I. and Subers, M.H. (1964). Effect of storage and processing temperatures on honey quality. Food Technology 18 (4): $153-156$. 
تأثير المعاملات الحرارية على تكون كل من الهيدركسي ميثايل فورفورال وفوق أكسيد الهيدروجين كلاليلين على تسخين عسل النحل ملئل

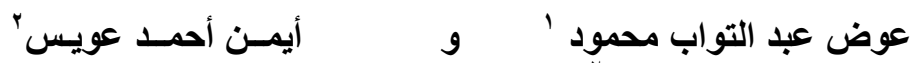

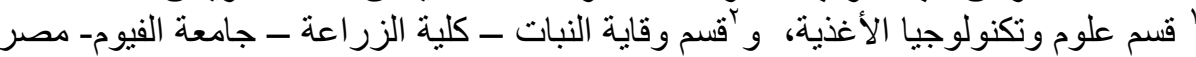

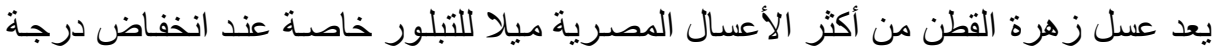

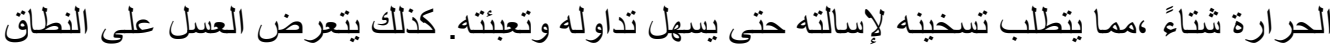
التجاري لعمليات التسخين بغرض البسترة و إطالة الفترة اللازمة للتبلور، حيث كيث يعد العسل المتبلور غير التير مقبول لدى كثير من المستهلكين.

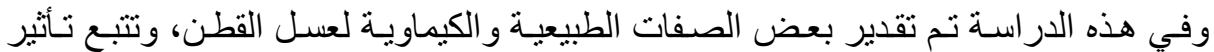

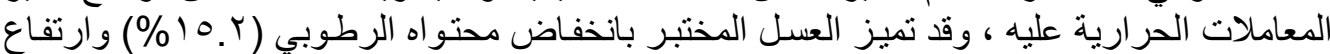

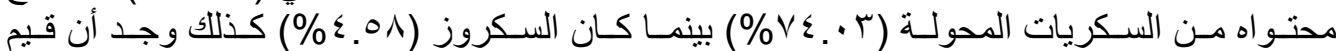

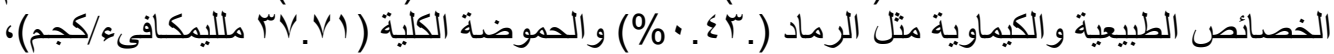

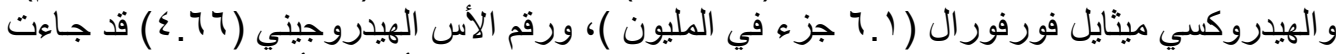

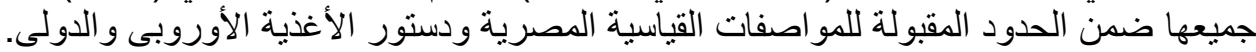

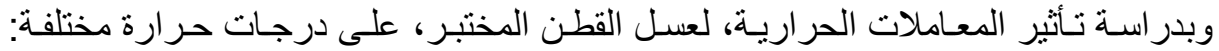

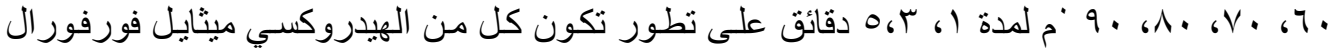

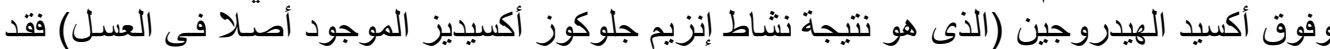

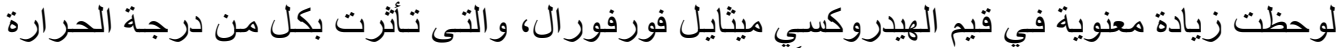

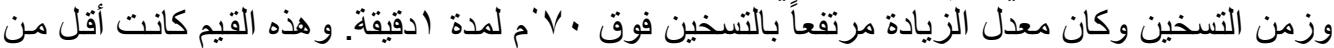

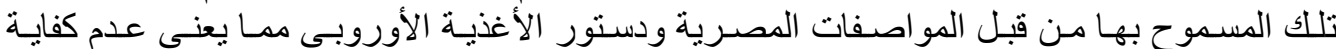

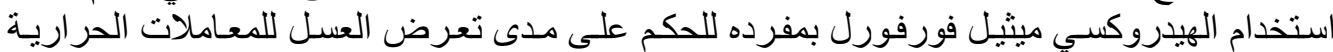

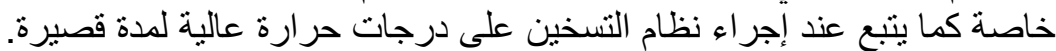

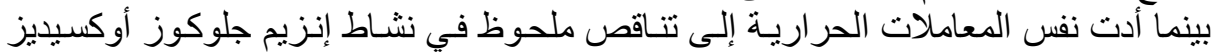

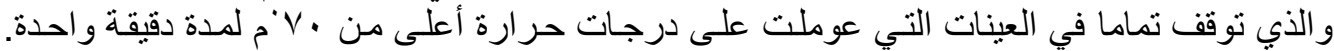

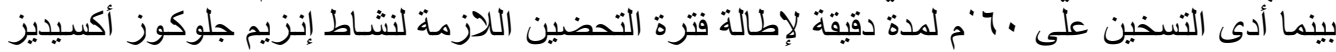

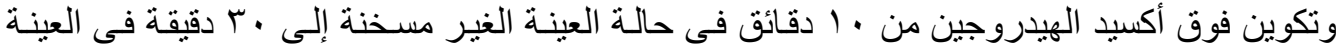

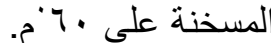

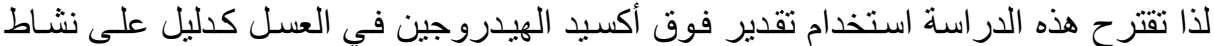

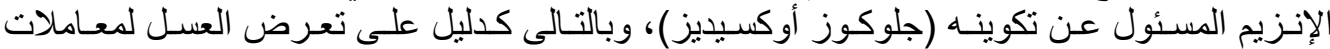
حرارية من عدمه.

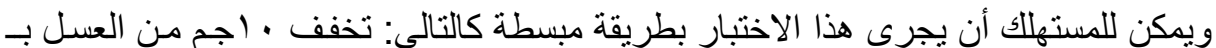

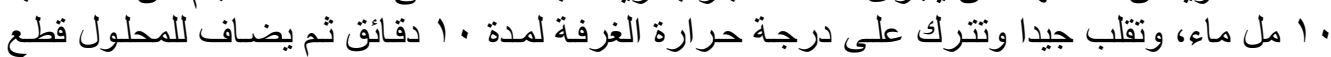

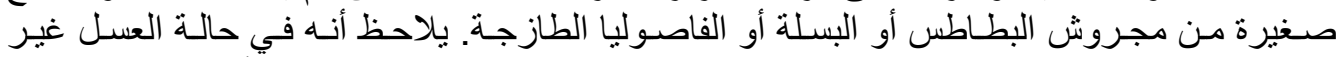

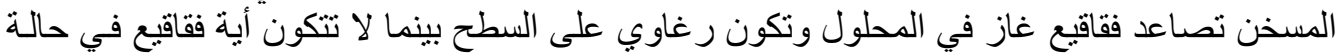

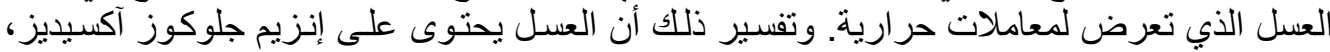

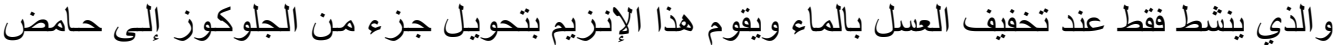

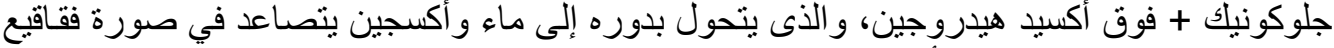
في وجود إنزيمات كتاليز وبير أكسيديز ، و الموجودة بالفعل ضمن مكونات الخضر الطازجة.

Fayoum J. Agric. Res. \& Dev., Vol.22, No.2, July, 2008 